\title{
Hypophosphatemic Osteomalacia Due to Drug-induced Fanconi's Syndrome Associated with Adefovir Dipivoxil Treatment for Hepatitis B
}

\author{
Hiroyuki Eguchi ${ }^{1}$, Munehisa Tsuruta ${ }^{1}$, Junichi Tani ${ }^{1}$, \\ Reiichiro Kuwahara $^{2}$ and Yuji Hiromatsu ${ }^{1}$
}

\begin{abstract}
We herein present the case of a 58-year-old Japanese man with Fanconi's syndrome with a 13-month history of bone pain in his ribs, hips, knees and ankles. He had been receiving low-dose adefovir dipivoxil (ADV) for the treatment of lamivudine-resistant chronic hepatitis B virus infection for eight years and subsequently developed severe hypophosphatemia and proximal renal tubule dysfunction. Magnetic resonance imaging showed multiple insufficiency fractures in the ribs, ileum, tibia and calcaneus. Whole-body bone scintigraphy demonstrated increased uptake in those areas. Following dose reduction of ADV and the administration of treatment with calcitriol and phosphates, the patient's serum phosphate level increased and his clinical symptoms improved. Physicians prescribing ADV should carefully monitor the renal function and serum phosphate level.
\end{abstract}

Key words: hypophosphatemia, osteomalacia, Fanconi’s syndrome, adefovir dipivoxil, hepatitis B virus

(Intern Med 53: 233-237, 2014)

(DOI: 10.2169/internalmedicine.53.1213)

\section{Introduction}

Adefovir dipivoxil (ADV) is a commonly used antiviral agent in the treatment of chronic hepatitis B virus (HBV) or human immunodeficiency virus (HIV) infection. Although high-dose ADV therapy (60-120 mg/day) is nephrotoxic (1), low-dose ADV therapy (10 mg/day) has been reported to be safe (2-7). However, there is an increasing number of reports stating that the long-term use of low-dose ADV causes proximal renal tubular dysfunction, a feature of Fanconi's syndrome, especially in East Asian populations (8-24). We herein report a case of severe hypophosphatemic osteomalacia with Fanconi's syndrome caused by low-dose ADV for the treatment of chronic hepatitis B virus infection.

\section{Case Report}

A 58-year-old man was referred to our clinic in January
2011 with a 13-month history of progressive generalized bone pain involving the bilateral rib cage, hips, knees and heels. The patient had been diagnosed with chronic active hepatitis B in 1992. He was positive for both the HBs and $\mathrm{HBe}$ antigens but negative $\mathrm{HBe}$ for antibodies. The level of HBV-DNA (TMA) was $7.7 \mathrm{LGE} / \mathrm{mL}$. Both the serum alanine aminotransferase (ALT) $(106 \mathrm{U} / \mathrm{L}$; normal range $<30$ $\mathrm{U} / \mathrm{L})$ and alpha-fetoprotein $(651 \mathrm{ng} / \mathrm{mL}$; normal range $<8.7$ $\mathrm{ng} / \mathrm{mL}$ ) levels were elevated. The patient was started on lamivudine (100 mg daily) therapy in February 2001. In September 2003, he developed lamivudine resistance; therefore, the lamivudine therapy was switched to ADV (10 mg daily) therapy. From September 2006 to November 2010, lamivudine was added to the ADV regimen. In December 2009, the patient developed pain in his heels and ankles. In January 2011, he came to our clinic with progressive generalized bone pain involving the bilateral rib cage, hips, knees, ankles and heels. He had a family history of HBV carriers (all brothers and sisters), HBV-related cirrhosis (mother) and

${ }^{1}$ Division of Endocrinology and Metabolism, Kurume University School of Medicine, Japan and ${ }^{2}$ Division of Gastroenterology, Department of Medicine, Kurume University School of Medicine, Japan

Received for publication June 21, 2013; Accepted for publication August 19, 2013

Correspondence to Dr. Hiroyuki Eguchi, egukuma.eguma@gmail.com 

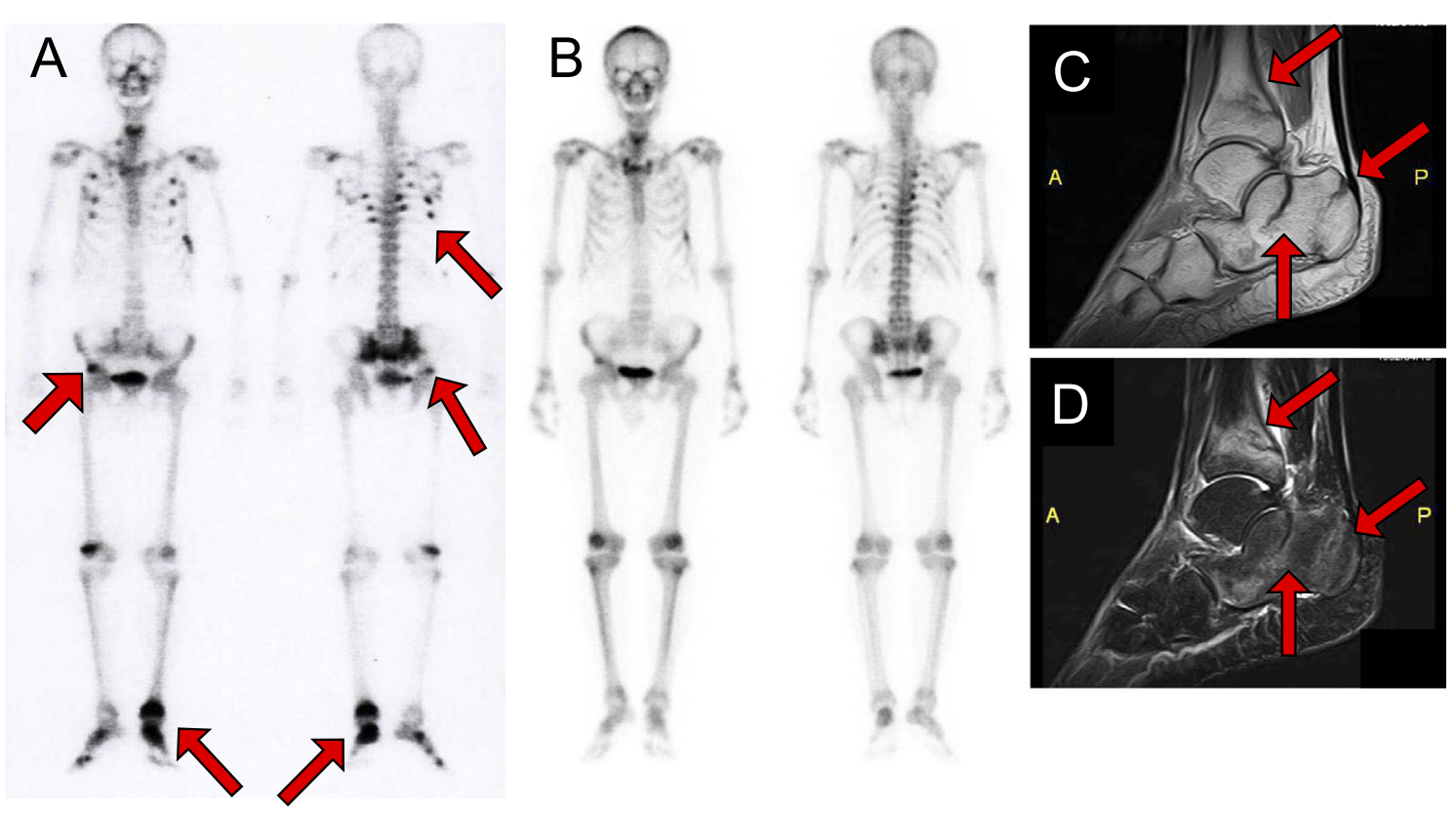

Figure 1. Whole-body ${ }^{99 \mathrm{~m}}$ Tc-methylene diphosphonate bone scintigraphy and magnetic resonance imaging (MRI). (A) The initial bone scan showed significant abnormal isotope uptake (arrows) in multiple ribs and the right ileum, left ankle and left heel. (B) A follow-up scan obtained six months after the reduction of adefovir, showed partial resolution of the abnormal isotope uptake. (C) MRI revealed insufficiency fractures (arrows) in the left distal tibia and left calcaneus. T1-weighted image shows low-intensity insufficiency fractures. (D) Short TI inversion recovery image shows high-intensity bone edema.

hepatocellular carcinoma (older sister).

The patient was $56.0 \mathrm{~kg}$ in weight and $161.6 \mathrm{~cm}$ in height and had a body mass index of $21.4 \mathrm{~kg} / \mathrm{m}^{2}$. His heart rate was $78 \mathrm{bpm}$ and his blood pressure was $128 / 74 \mathrm{mmHg}$. On a physical examination, he had generalized bone tenderness, especially in the regions mentioned above. No strumas were palpable. There were no specific signs in the respiratory, digestive or circulatory systems. There was no edema in the patient's legs. The laboratory data revealed hypophosphatemia $(1.39 \mathrm{mg} / \mathrm{dL}$; normal range $2.5-4.5 \mathrm{mg} / \mathrm{dL})$, hypouricemia $(2.82 \mathrm{mg} / \mathrm{dL}$; normal range $3.60-7.00 \mathrm{mg} / \mathrm{dL}$ ) and increased levels of alkaline phosphatase (ALP, $921 \mathrm{U} / \mathrm{L}$; normal range 115-359 U/L) and bone alkaline phosphatase (BAP, 76.1 U/L; normal range 3.7-20.9 $\mu \mathrm{g} / \mathrm{L}$ ). The serum creatinine level was normal $(1.06 \mathrm{mg} / \mathrm{dL}$; normal range 0.6$1.10 \mathrm{mg} / \mathrm{dL}$ ). However, it gradually increased up to 1.23 $\mathrm{mg} / \mathrm{dL}$. The serum calcium $(9.62 \mathrm{mg} / \mathrm{dL})$, intact parathyroid hormone (PTH, $26 \mathrm{pg} / \mathrm{mL}$; normal range $10-65 \mathrm{mg} / \mathrm{dL}$ ) and 1,25 dihydroxyvitamin $\mathrm{D}(46.4 \mathrm{pg} / \mathrm{mL}$; normal range $20.0-$ $60.0 \mathrm{pg} / \mathrm{mL}$; 1,25-hydroxyvitamin D RIA kit 'TFB'; Immunodiagnostic Systems Ltd., Boldon, UK) levels were all within the normal range. The serum fibroblast growth factor 23 level was low $(3.8 \mathrm{pg} / \mathrm{mL}$; normal range $10-50 \mathrm{pg} / \mathrm{mL}$; FGF23 ELISA kit; Kainos Laboratories, Inc., Tokyo, Japan) (25). The serum $\mathrm{FT}_{3}$ level was $3.0 \mathrm{pg} / \mathrm{mL}(1.9-3.5 \mathrm{pg} /$ $\mathrm{mL})$ and the $\mathrm{FT}_{4}$ level was $0.90(0.88-1.56 \mathrm{ng} / \mathrm{dL})$, both within the normal range; however, the TSH $(5.67 \mu \mathrm{U} / \mathrm{mL}$; normal range $0.210-3.850 \mu \mathrm{U} / \mathrm{mL}$ ) level was slightly ele- vated. Anti-thyroid peroxidase (TPO) antibodies were positive $(353.3 \mathrm{IU} / \mathrm{mL}$; normal range $<5.0 \mathrm{IU} / \mathrm{mL})$. There was no metabolic acidosis. The patient's blood $\mathrm{HCO}_{3}$ was 22.7 $\mathrm{mEq} / \mathrm{L}$. A urinalysis showed proteinuria $(100 \mathrm{mg} / \mathrm{dL})$, glucosuria $(250 \mathrm{mg} / \mathrm{dL})$ and general aminoaciduria. These findings suggested that the patient had Fanconi's syndrome and chronic thyroiditis. Magnetic resonance imaging (MRI) revealed multiple insufficiency fractures in the bilateral ribs, ileum, right femur, left distal tibia and left calcaneus. ${ }^{99 \mathrm{~m}} \mathrm{Tc}$ hydroxymethylene diphosphonate (HMDP) scintigraphy demonstrated significant abnormal uptake in the ribs, left shoulder, pelvis, right knee and left ankle and heel (Fig. 1). We diagnosed the patient with osteomalacia due to Fanconi's syndrome secondary to ADV therapy for chronic hepatitis B and chronic thyroiditis. Following the reduction of the dose of ADV from $10 \mathrm{mg}$ every day to every other day with supplementation with alfacalcidol $(4 \mu \mathrm{g} / \mathrm{day})$ and phosphate $(1.5 \mathrm{~g} / \mathrm{day})$, the patient's serum phosphate and creatinine levels normalized, and both the glycosuria and proteinuria resolved (Fig. 2). Clinical symptoms, such as bone pain, also disappeared.

\section{Discussion}

$\mathrm{ADV}$, a nucleotide analog widely used in the management of patients with chronic hepatitis B, can be nephrotoxic, even at low doses. ADV-induced nephrotoxicity is dosedependent. The incidence of an increase in the level of cre- 


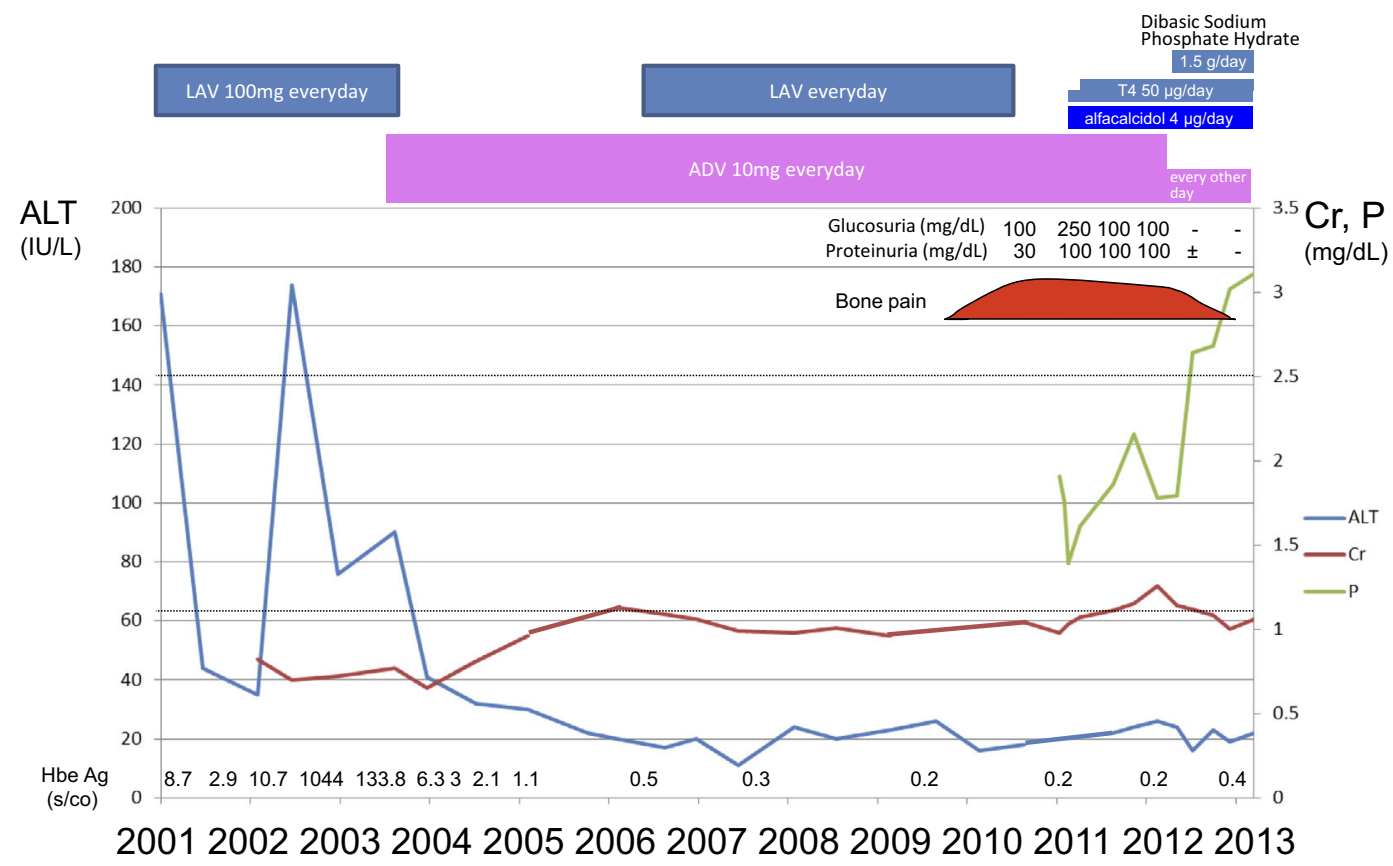

Figure 2. Clinical course. LAV: lamivudine, ADV: adefovir, ALT: alanine aminotransferase, Cr: creatinine, P: phosphate, HBeAg: hepatitis B e antigen, FT 3 : free triiodothyronine, FT 4 : free thyroxine

atinine of greater than $0.5 \mathrm{mg} / \mathrm{mL}$ from baseline is $35 \%$ at 48 weeks and $50 \%$ at 72 weeks in patients receiving 120 $\mathrm{mg} /$ day of ADV (1). Hypophosphatemia occurs in $50 \%$ of patients after 48 weeks and $61 \%$ of patients after 72 weeks of ADV treatment (1). Among patients treated with $30 \mathrm{mg}$ of $\mathrm{ADV}, 21 \%$ exhibit an increase in creatinine of more than $0.5 \mathrm{mg} / \mathrm{dL}$ from baseline by week 48 , while $16 \%$ are hypophosphatemic (6). Conversely, a $10-\mathrm{mg} /$ day dose of ADV is generally well tolerated, with no increases in adverse events or laboratory abnormalities compared with a placebo, as reported in two registered trials $(2,3)$. In subsequent studies, the incidence of an increase in serum creatinine of $0.5 \mathrm{mg}$ / $\mathrm{dL}$ or more has been reported to occur in $2-8 \%$ of patients on long-term ADV therapy (4-7, 26-29). However, this is not the case in the Japanese population. Tamori et al. (10) reported that the serum creatinine levels increased in 14 $(38 \%)$ of 37 patients, while the serum phosphate levels decreased to below $2.5 \mathrm{mg} / \mathrm{mL}$ in six (16\%) of 37 patients during therapy. More recently, Tanaka et al. (20) reported that, among 292 patients, 28 (9.6\%) developed renal impairment [defined as an estimated glomerular filtration rate (eGFR) of $\left.<50 \mathrm{~mL} / \mathrm{min} / 1.73 \mathrm{~m}^{2}\right]$ and $14(5.2 \%)$ developed persistent hypophosphatemia, suggesting that the Japanese may be more susceptible to renal tubular toxicity. Further studies are required to clarify this issue.

There is an increasing number of case reports from East Asian countries that show that even patients on low-dose ADV exhibit nephrotoxicity (Table). The ages of these patients varied from 22 to 74 years, with a median of 56 years. The male/female ratio was 4.5 . Symptoms became clinically evident after a median of 36 months (range 6-71 months). Muscle weakness and generalized bone pain were the major symptoms. Following discontinuation or reduction of the dose of ADV, the serum phosphate levels and clinical symptoms improved in almost all cases, suggesting that ADV-induced nephrotoxicity is reversible.

ADV-induced nephrotoxicity is characterized by a decrease in the level of phosphate and a slight increase in the level of creatinine, resulting in renal proximal tubular dysfunction, the features of Fanconi's syndrome (30). Although the mechanisms underlying the development of ADVinduced nephrotoxicity are not fully understood, ADV may cause apoptosis or mitochondrial toxicity of the renal tubular epithelium (31). The human organic anion transporter-1 (hOAT1), a basolateral membrane protein of the proximal tubule, mediates the active uptake of ADV from the blood into proximal tubular cells (32). ADV is secreted into the urine by multidrug resistance proteins (MRPs) 2, 4 and 5, which are located on the apical side of proximal tubular cells (33). The overexpression of hOAT1 or underexpression of MRPs, therefore, may result in the accumulation of ADV in the renal tubules and subsequent tubular toxicity. Genetic polymorphisms, which affect the expression of these proteins, may contribute to ADV-induced nephrotoxicity $(34,35)$.

In conclusion, we herein reported a case of severe hypophosphatemic osteomalacia with Fanconi's syndrome caused by the long-term use of low-dose ADV for the treatment of chronic hepatitis B. There is an increasing number of similar reports from East Asian countries, suggesting that ethnic factors or an increased number of patients with persistent $\mathrm{HBV}$ infection in these areas may influence the development 
Table. Clinical Characteristics of the 22 Patients with Hypophosphatemic Osteomalacia Induced by Low-dose Adefovir Therapy for Chronic Hepatitis B

\begin{tabular}{|c|c|c|c|c|c|c|c|c|c|c|c|c|}
\hline \multirow[b]{2}{*}{ Reference } & \multirow[b]{2}{*}{ Ethnicity } & \multirow[b]{2}{*}{ Sex } & \multirow[b]{2}{*}{$\begin{array}{l}\text { Age } \\
(\mathrm{yr})\end{array}$} & \multicolumn{2}{|c|}{ Duration of ADV use to } & \multicolumn{3}{|c|}{ Baseline serum } & \multicolumn{2}{|c|}{ Follow-up serum } & \multirow[b]{2}{*}{ Treatment strategies } & \multirow[b]{2}{*}{ Prognosis } \\
\hline & & & & $\begin{array}{c}\text { onset } \\
\text { symptoms } \\
\text { (months) }\end{array}$ & $\begin{array}{l}\text { find hypo- } \\
\text { phosphatemia } \\
\text { (months) }\end{array}$ & $\begin{array}{l}\text { phosphate } \\
\text { (mg/dL) }\end{array}$ & $\begin{array}{l}\text { creatinine } \\
(\mathrm{mg} / \mathrm{dL})\end{array}$ & $\begin{array}{c}\text { ALP } \\
\text { (IU/L) } \\
\text { (normal } \\
\text { range) }\end{array}$ & $\begin{array}{l}\text { phosphate } \\
(\mathrm{mg} / \mathrm{dL})\end{array}$ & $\begin{array}{l}\text { creatinine } \\
(\mathrm{mg} / \mathrm{dL})\end{array}$ & & \\
\hline 8 & Korean & M & 42 & 6 & 18 & 1.2 & 1 & $\begin{array}{c}1722 \\
(80-270)\end{array}$ & 2.2 & NA & $\begin{array}{l}\text { ADV cessation, phosphate } \\
\text { supplementation }\end{array}$ & improved \\
\hline 9 & Unspecified & M & 58 & 8 & 8 & 0.93 & 1.86 & NA & NA & NA & ADV cessation & $\begin{array}{l}\text { worsened } \\
\text { creatinine } \\
\text { clearance }\end{array}$ \\
\hline 10 & Japanese & $\mathrm{F}$ & 57 & 9 & 14 & 1.9 & 0.88 & $\begin{array}{c}800 \\
(30-397)\end{array}$ & 3.5 & NA & $\begin{array}{l}\text { ADV reduction, phosphate } \\
\text { supplementation }\end{array}$ & improved \\
\hline 11 & Japanese & M & 48 & 20 & 50 & 1.4 & 1.1 & $\begin{array}{c}3410 \\
(116-280)\end{array}$ & 3 & 1.3 & $\begin{array}{l}\text { ADV reduction, phosphate } \\
\text { supplementation }\end{array}$ & improved \\
\hline 12 & Korean & M & 66 & 36 & 36 & 1.7 & 1.2 & $\begin{array}{c}157 \\
\text { (NA) }\end{array}$ & 2 & NA & Phosphate supplementation & improved \\
\hline 13 & Korean & M & 47 & 32 & 38 & 1.3 & 1.35 & $\begin{array}{c}321 \\
(38-126)\end{array}$ & 2.4 & 0.92 & $\begin{array}{l}\text { ADV cessation, phosphate } \\
\text { supplementation }\end{array}$ & improved \\
\hline 14 & Japanese & $\mathrm{F}$ & 70 & 12 & 30 & 1.5 & 0.95 & $\begin{array}{c}1977 \\
(115-359)\end{array}$ & $\begin{array}{l}\text { Normal } \\
\text { (data NA) }\end{array}$ & NA & $\begin{array}{l}\text { Switched with entecavir, } \\
\text { alphacalcidol }\end{array}$ & improved \\
\hline 14 & Japanese & M & 60 & 36 & 18 & 1.7 & 1.34 & $\begin{array}{c}864 \\
(115-359)\end{array}$ & $\begin{array}{l}\text { Normal } \\
\text { (data NA) }\end{array}$ & NA & $\begin{array}{l}\text { Phosphate supplementation, } \\
\text { alphacalcidol }\end{array}$ & improved \\
\hline 15 & Japanese & M & 48 & 36 & 36 & 2 & 1.6 & $\begin{array}{l}1314 \\
\text { (NA) }\end{array}$ & 2.3 & NA & $\begin{array}{l}\text { ADV reduction }(30 \mathrm{mg} / \\
\text { week), calcitriol }\end{array}$ & improved \\
\hline 16 & $\begin{array}{l}\text { Chinese } \\
\text { Cambodian }\end{array}$ & M & 40 & 22 & 27 & 2.0 & NA & $\begin{array}{c}271 \\
(\mathrm{NA})\end{array}$ & 2.98 & NA & $\begin{array}{l}\text { ADV cessation, phosphate, } \\
\text { calcium, vitamin D3 } \\
\text { supplementation }\end{array}$ & improved \\
\hline 16 & $\begin{array}{l}\text { Chinese } \\
\text { Cambodian }\end{array}$ & $\mathrm{F}$ & 53 & 58 & 64 & 1.53 & NA & NA & 2.98 & NA & $\begin{array}{l}\text { ADV cessation, phosphate, } \\
\text { calcitriol }\end{array}$ & improved \\
\hline 17 & Chinese & $\mathrm{F}$ & 74 & 48 & 48 & 1.52 & 0.91 & $\begin{array}{c}698 \\
(43-141)\end{array}$ & $\begin{array}{c}\text { Normal } \\
\text { (data NA) }\end{array}$ & NA & $\begin{array}{l}\text { Switched with entecavir, } \\
\text { calcitriol, phosphate } \\
\text { supplementation }\end{array}$ & improved \\
\hline 18 & Chinese & M & 22 & 38 & 48 & 1.15 & NA & $\begin{array}{c}492 \\
\text { (NA) }\end{array}$ & NA & NA & $\begin{array}{l}\text { ADV cessation, phosphate } \\
\text { supplementation }\end{array}$ & NA \\
\hline 19 & Unspecified & M & 68 & 20 & 38 & 2.23 & 1.5 & $\begin{array}{c}443 \\
\text { (NA) }\end{array}$ & NA & NA & $\begin{array}{l}\text { Switched with entecavir, } \\
\text { phosphate, cholecalciferol }\end{array}$ & improved \\
\hline 20 & Japanese & M & 62 & 47 & 60 & 2 & 0.7 & $\begin{array}{c}1594 \\
(115-359)\end{array}$ & $\begin{array}{l}\text { Normal } \\
\text { (data NA) }\end{array}$ & NA & $\begin{array}{l}\text { Switched with entecavir, } \\
\text { eldecalcitol }\end{array}$ & improved \\
\hline 21 & Korean & M & 62 & 36 & 60 & 2.2 & 1.49 & $\begin{array}{c}328 \\
(53-128)\end{array}$ & 1.8 & NA & $\begin{array}{l}\text { Phosphate, } \\
\text { calcitriol }\end{array}$ & improved \\
\hline 21 & Korean & M & 54 & 41 & 59 & 1.0 & 1.12 & $\begin{array}{c}432 \\
(53-128)\end{array}$ & NA & NA & Switched with entecavir & improved \\
\hline 22 & Chinese & M & NA & $>36$ & $>36$ & 1.98 & 0.98 & $\begin{array}{c}420 \\
(40-150)\end{array}$ & 3.53 & NA & $\begin{array}{l}\text { Switched with entecavir, } \\
\text { calcitriol }\end{array}$ & improved \\
\hline 22 & Chinese & M & NA & $>36$ & $>36$ & 1.15 & 1.1 & $\begin{array}{c}317 \\
(40-150)\end{array}$ & 2.54 & NA & $\begin{array}{l}\text { Switched with entecavir, } \\
\text { calcitriol }\end{array}$ & improved \\
\hline 23 & Japanese & M & 56 & NA & 48 & NA & 2.23 & $\begin{array}{c}674 \\
(104-338)\end{array}$ & NA & 1.5 & ADV reduction & improved \\
\hline 24 & Chinese & M & 48 & 54 & 68 & 1.1 & 1.03 & $\begin{array}{c}297 \\
(40-150)\end{array}$ & 0.78 & 1.07 & ADV cessation & improved \\
\hline present case & Japanese & M & 58 & 71 & 88 & 1.39 & 1.06 & $\begin{array}{c}921 \\
(115-359)\end{array}$ & 3.11 & 1.06 & $\begin{array}{l}\text { ADV reduction, phosphate, } \\
\text { alfacalcidol }\end{array}$ & improved \\
\hline
\end{tabular}

M: male, F: female, NA: not avairable, ADV: adefovir, ALP: alkaline phosphatase

of this side effect. Following the cessation or dose reduction of $\mathrm{ADV}$ and the administration of treatment with alfacalcidol and phosphates, the serum phosphate level increased and the patient's clinical symptoms improved. Physicians prescribing ADV should be aware of the late onset of this complication and should carefully monitor the renal function and serum phosphate level.

The authors state that they have no Conflict of Interest (COI).

\section{References}

1. Kahn J, Lagakos S, Wulfsohn M, et al. Efficacy and safety of adefovir dipivoxil with antiretroviral therapy: a randomized controlled trial. JAMA 282: 2305-2312, 1999.

2. Marcellin P, Chang TT, Lim SG, et al; Adefovir Dipivoxil 437 Study Group. Adefovir dipivoxil for the treatment of hepatitis B e antigen-positive chronic hepatitis B. N Engl J Med 348: 808-816, 2003.

3. Hadziyannis SJ, Tassopoulos NC, Heathcote EJ, et al; Adefovir Dipivoxil 438 Study Group. Adefovir dipivoxil for the treatment of hepatitis B e antigen-negative chronic hepatitis B. N Engl $\mathrm{J}$ Med 348: 800-807, 2003. 
4. Marcellin P, Chang TT, Lim SG, et al. Long-term efficacy and safety of adefovir dipivoxil for the treatment of hepatitis B e antigen-positive chronic hepatitis B. Hepatology 48: 750-758, 2008

5. Hadziyannis SJ, Tassopoulos NC, Heathcote EJ, et al; Adefovir Dipivoxil 438 Study Group. Long-term therapy with adefovir dipivoxil for HBeAg-negative chronic hepatitis B for up to 5 years. Gastroenterology 131: 1743-1751, 2006.

6. Izzedine H, Hulot JS, Launay-Vacher V, et al; Adefovir Dipivoxil International 437 Study Group, Adefovir Dipivoxil International 438 Study Group. Renal safety of adefovir dipivoxil in patients with chronic hepatitis B: two double-blind, randomized, placebocontrolled studies. Kidney Int 66: 1153-1158, 2004.

7. Ha NB, Ha NB, Garcia RT, et al. Renal dysfunction in chronic hepatitis B patients treated with adefovir dipivoxil. Hepatology 50: 727-734, 2009.

8. Lee HJ, Choi JW, Kim TN, Eun JR. A case of severe hypophosphatemia related to adefovir dipivoxil treatment in a patient with liver cirrhosis related to hepatitis B virus. Korean J Hepatol 14: 381-386, 2011 (in Korean, Abstract in English).

9. Izzedine H, Kheder-Elfekih R, Housset P, Sarkozy C, Brocheriou I, Deray G. Adefovir dipivoxil-induced acute tubular necrosis and Fanconi syndrome in a renal transplant patient. AIDS 23: 544-545, 2009.

10. Tamori A, Enomoto M, Kobayashi S, et al. Add-on combination therapy with adefovir dipivoxil induces renal impairment in patients with lamivudine-refractory hepatitis B virus. J Viral Hepat 17: 123-129, 2009.

11. Minemura M, Tokimitsu Y, Tajiri K, et al. Development of osteomalacia in a post-liver transplant patient receiving adefovir dipivoxil. World J Hepatol 2: 442-446, 2010.

12. Kwon SY, Ahn SY, Ko SY, et al. A case of osteomalacia related to adefovir in a patient with chronic hepatitis B. Korean J Gastroenterol 56: 117-120, 2010 (in Korean, Abstract in English).

13. Jung YK, Yeon JE, Choi JH, et al. Fanconi's syndrome associated with prolonged adefovir dipivoxil therapy in a hepatitis B virus patient. Gut Liver 4: 389-393, 2010.

14. Kawate H, Taketomi A, Watanabe T, et al. Hypophosphatemic osteomalacia as a long-term complication after liver transplantation. Transplantation 91: e6-e8, 2011.

15. Kishimoto Y, Okano T, Teshima R. Osteomalacia caused by antiviral drug for chronic hepatitis B: A case report. Orthopedics \& Traumatology 60: 148-151, 2011 (in Japanese, Abstract in English).

16. Girgis CM, Wong T, Ngu MC, et al. Hypophosphataemic osteomalacia in patients on adefovir dipivoxil. J Clin Gastroenterol $\mathbf{4 5}$ 468-473, 2011.

17. Law ST, Li KK, Ho YY. Nephrotoxicity, including acquired Fanconi's syndrome, caused by adefovir dipivoxil is there a safe dose? J Clin Pharm Ther 37: 128-131, 2012.

18. Li L, Dong GF, Zhang X, Xie YS. Adefovir dipivoxil-induced Fanconi syndrome and hypophosphatemic osteomalacia associated with muscular weakness in a patient with chronic hepatitis B. Nan Fang Yi Ke Da Xue Xue Bao 31: 1956, 2011 (in Chinese, Abstract in English).

19. Fabbriciani G, de Socio GV, Massarotti M, Ceriani R, Marasini B. Adefovir induced hypophosphatemic osteomalacia. Scand J Infect Dis 43: 990-992, 2011.
20. Tanaka M, Setoguchi T, Ishidou $Y$, et al. Pathological femoral fractures due to osteomalacia associated with adefovir dipivoxil treatment for hepatitis B: a case report. Diagn Pathol 7: 108, 2012.

21. Kim du H, Sung DH, Min YK. Hypophosphatemic osteomalacia induced by low-dose adefovir therapy: focus on manifestations in the skeletal system and literature review. J Bone Miner Metab 31: 240-246, 2013.

22. Dai CL, Zhu M, Wang BP, et al. Prolonged adefovir therapy associated Fanconi syndrome and interstitial nephritis in hepatitis B. Intern Med J 42: 955-957, 2012.

23. Shimohata H, Sakai S, Ogawa Y, Hirayama K, Kobayashi M. Osteomalacia due to Fanconi's syndrome and renal failure caused by long-term low-dose adefovir dipivoxil. Clin Exp Nephrol 17: 147148, 2013.

24. Wu C, Zhang H, Qian Y, Wang L, Gu X, Dai Z. Hypophosphatemic osteomalacia and renal Fanconi syndrome induced by low-dose adefovir dipivoxil: a case report and literature review suggesting ethnic predisposition. J Clin Pharm Ther 38: 321-326, 2013.

25. Yamazaki Y, Okazaki R, Shibata M, et al. Increased circulatory level of biologically active full-length FGF-23 in patients with hypophosphatemic rickets/osteomalacia. J Clin Endocrinol Metab 87: 4957-4960, 2002.

26. Zeng M, Mao Y, Yao G, et al. A double-blind randomized trial of adefovir dipivoxil in Chinese subjects with $\mathrm{HBeAg}$-positive chronic hepatitis B. Hepatology 44: 108-116, 2006.

27. Lampertico $\mathrm{P}$, Viganò $\mathrm{M}$, Manenti E, Iavarone M, Sablon E, Colombo M. Low resistance to adefovir combined with lamivudine: a 3-year study of 145 lamivudine-resistant hepatitis B patients. Gastroenterology 133: 1445-1451, 2007.

28. Rapti I, Dimou E, Mitsoula P, Hadziyannis SJ. Adding-on versus switching-to adefovir therapy in lamivudine-resistant HBeAgnegative chronic hepatitis B. Hepatology 45: 307-313, 2007.

29. Fung SK, Chae HB, Fontana RJ, et al. Virologic response and resistance to adefovir in patients with chronic hepatitis B. J Hepatol 44: 283-290, 2006

30. Viganò $M$, Lampertico $P$, Colombo $M$. Drug safety evaluation of adefovir in HBV infection. Expert Opin Drug Saf 10: 809-818, 2011.

31. Tanji N, Tanji K, Kambham N, Markowitz GS, Bell A, D'agati VD. Adefovir nephrotoxicity: possible role of mitochondrial DNA depletion. Hum Pathol 32: 734-740, 2001.

32. Cihlar T, Lin DC, Pritchard JB, Fuller MD, Mendel DB, Sweet DH. The antiviral nucleotide analogs cidofovir and adefovir are novel substrates for human and rat renal organic anion transporter 1. Mol Pharmacol 56: 570-580, 1999.

33. Miller DS. Nucleoside phosphonate interactions with multiple organic anion transporters in renal proximal tubule. J Pharmacol Exp Ther 299: 567-574, 2001.

34. Viganò M, Lampertico $\mathrm{P}$, Dongiovanni $\mathrm{P}$, et al. A drug transporter gene polymorphism predicts renal tubular toxicity in patients with chronic hepatitis B on long-term adefovir and lamivudine combination. J Hepatol 52 Supplement 1: S7, 2010.

35. Bleasby K, Hall LA, Perry JL, Mohrenweiser HW, Pritchard JB. Functional consequences of single nucleotide polymorphisms in the human organic anion transporter hOAT1 (SLC22A6). J Pharmacol Exp Ther 314: 923-931, 2005.

(C) 2014 The Japanese Society of Internal Medicine http://www.naika.or.jp/imonline/index.html 